\title{
WYKAZ DOKTORÓW WYPROMOWANYCH PRZEZ PROFESORA FRANCISZKA GRONOWSKIEGO
}

Ignacy Chrzanowski, Ekonomiczne skutki awaryjności polskiej floty handlowej oraz metody działalności zapobiegawczej (1970).

Władysław Magiera, Czynniki ograniczające i stymulujace rozwój floty na polskich drogach wodnych (1971).

Jerzy Leszczyński, Syntetyczne mierniki oceny działalności przedsiębiorstw żeglugi morskiej (1971).

Aleksander Walczak, Skutki ekonomiczne awarii nawigacyjnych, ich przyczyny oraz metody zapobiegania (1971).

Krzysztof Luks, Transport zaplecza w obsłudze zespołu portowego Szczecin-Świnoujście (1971).

Jerzy Korzonek, Kryteria i metody określania optymalnej wielkości potencjału usługowego portu morskiego (1972).

Mirosław Zajączkowski, Mierniki oceny podstawowej działalności eksploatacyjnej portu morskiego (1972).

Aleksander Januszkiewicz, Przesłanki ekonomiczne zastosowania kontenerów w obrotach polskiego handlu zagranicznego (1973).

Bożena Schnotale, Gestia transportowa jako czynnik aktywizujący rozwój polskiej floty handlowej (1973).

Józef Burka, Ceny ustug transportowych jako kryterium podziału przewozów między gałęzie transportu (1974).

Jacek Ławicki, Węzłowe problemy światowych przewozów siarki droga morska (1975).

Lech Łyczywek, Rola żeglugi morskiej w gospodarce Finlandii (1976).

Zygfryd Góral, Analiza przyczyn i skutków wypadków morskich jako podstawa polityki prewencyjnej (1977).

Zenon Sosnowski, Usługi komplementarne w obsłudze statków i ładunków w zespole portowym Szczecin-Świnoujście (1977).

Wojciech Milke, Analiza możliwości wprowadzenia barkowców do polskiej floty handlowej (1978).

Władysław Nowak, Podstawowe czynniki rozwoju żeglugi śródlądowej w systemach transportowych wybranych państw europejskich (1979).

Leszek Plewiński, Czynniki kształtujące politykę inwestycji tonażowych żeglugi trampowej (1980). Stanisław Kuszmider, Efekty ekonomiczne optymalizacji zużycia paliw na statkach PMH (1982). Jadwiga Żaboklicka, Podstawowe problemy przewozu surowców fosforonośnych importowanych do Polski droga morska (1982).

Ly Bach Chan, Śródlądowe drogi wodne Wietnamu Płn. i ich wykorzystanie transportowe (1982). 
Henryk Salmonowicz, Możliwości aktywizacji funkcji transportowej Odry w świetle czynników warunkujących rozwój żeglugi śródlądowej (1988).

Dariusz Bernacki, Ocena relacji produkcyjnych w polskich portach morskich na przykładzie Zarządu Portu Szczecin-Świnoujście (1989).

Marcel Kamba Kibatshi, Transport morski i śródlądowy w przekształceniach systemu transportowego Republiki Zair (1994).

Michał Pluciński, Relacje ekonomiczno-społeczne między gmina miasta portowego a portem morskim na przykładzie Szczecina i Świnoujścia (2002). 